\title{
Asymptomatic degenerative mitral regurgitation - timing the surgery
}

\section{(iD) Petra Grubić \\ Rotkvić* \\ (1)Zrinka Planinić}

University Hospital "Sveti Duh", Zagreb, Croatia

\begin{abstract}
KEYWORDS: asymptomatic mitral regurgitation, watchful waiting, mitral valve surgery. CITATION: Cardiol Croat. 2021;16(9-10):308. | https://doi.org/10.15836/ccar2021.308
\end{abstract}

*ADDRESS FOR CORRESPONDENCE: Petra Grubić Rotkvić, Klinička bolnica "Sveti Duh", Sv. Duh 64, HR-10000 Zagreb, Croatia. / Phone: +385-91-3714-424 / E-mail: petra.grubic84@gmail.com

ORCID: Petra Grubić Rotkvić, https://orcid.org/0000-0002-2587-1932 • Zrinka Planinić, https://orcid.org/0000-0001-8664-3338

\section{||||||||||||||||||||||||||||||||||||||||||||||||||||||||||||||||||||||||||||||||||||||||||||||||||||||||||||||||||||||||||||||||||||||||}

Primary degenerative mitral regurgitation (MR) is caused by abnormality of one or more components of the valve apparatus, whereas functional MR is a left ventricular (LV) disease. Mitral valve (MV) surgery is required to address the primary process in degenerative MR (DMR), but the timing of MV surgery is controversial in asymptomatic patients. The "watchful waiting" strategy is dictated by a timely LV dysfunction recognition. The guidelines recommend MV surgery in asymptomatic patients with LV ejection fraction (EF) $<60 \%$, LV end-systolic diameter 40 to $45 \mathrm{~mm}$, new-onset atrial fibrillation, resting systolic pulmonary artery pressure (sPAP) exceeding $50 \mathrm{mmHg}$, or if surgical risk is low with high likelihood of durable MV repair ${ }^{1}$.

Current accepted echocardiographic measurements of LV function are not sensitive enough for early myocardial injury detection since end-systolic dimensions and $\mathrm{EF}$ are affected by the different loading conditions in MR. The key is to identify hemodynamic consequences early in MR time course so that timely surgery may reverse them before becoming irreversible ${ }^{2}$. Studies struggle on identifying other parameters or methods that could detect subclinical LV systolic dysfunction and predict postoperative outcomes such as: 1) brain natriuretic peptide (BNP) (there is no specific BNP cutoff of BNP for intervention, but a serial increase in BNP may reflect LV dysfunction and increased reliance on preload reserve in maintaining cardiac output); 2) LV global longitudinal strain (GLS) (a sensitive method for early detection of LV dysfunction, independently associated with mortality, add incremental data to surgical timing, with cutoffs $-17.9 \%$ and $-21.7 \%$ shown in studies that differentiate patients at higher risk, and with the possibility to detect relative change of GLS from baseline as in cardio-oncology); 3 ) left atrial size and strain; 4) echocardiographic exercise testing (good contractile reserve measured by LVEF and LV GLS and preserved exercise capacity without SPAP or MR worsening are reassuring parameters for a beneficial outcome); 5) cardiac magnetic resonance imaging (it can potentially reclassify MR severity providing valuable data on LV function and volumes) ${ }^{1-3}$.

Lastly, determination of proper timing for DMR surgery remains challenging and requires more studies.
RECEIVED:

July 26, 2021

ACCEPTED:

August 5, 2021
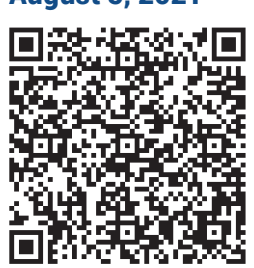

$\square$ Cardiologia Croatica 2021;16(9-10):308.
5. kongres Radne skupine za bolesti srčanih zalistaka Hrvatskoga kardiološkog društva s međunarodnim sudjelovanjem $5^{\text {th }}$ Congress of the Working Group on Valvular Diseases of the Croatian Cardiac Society with international participation September 2-4, 2021, Zagreb, Croatia 